\title{
Psychoticism as a Correlate of Involvement in Risky Sexual Behavior Among Students in Secondary Schools in Nyakach Sub-County Kisumu County, Kenya
}

\author{
Omanyo Abraham Otieno \\ Department of Psychology, Maseno University, Kisumu, Kenya
}

Email address:

abrahamotieno@yahoo.com

To cite this article:

Omanyo Abraham Otieno. Psychoticism as a Correlate of Involvement in Risky Sexual Behavior Among Students in Secondary Schools in Nyakach Sub-County Kisumu County, Kenya. American Journal of Applied Psychology. Vol. 7, No. 1, 2018, pp. 14-20. doi: 10.11648/j.ajap.20180701.13

Received: October 2, 2017; Accepted: October 17, 2017; Published: March 27, 2018

\begin{abstract}
Risky sexual Behavior is a common habit among young people in the world, but its relation with Psychoticism has not been explored exhaustively, especially in Kenya. The study aimed at establishing correlation between Psychoticism and involvement in risky sexual Behavior among students in secondary schools in Nyakach Sub-county using a Correlational research design. A multistage random sampling was used to determine a sample size of 46 schools (88\%) and 390 students (22\%). Data was collected using Eysenck's Personality Questionnaire (EPQ) and Risky Sexual Behavior Questionnaires. Data was analyzed using descriptive statistics (frequency, percentages and mean) as well as inferential statistics (Pearson Correlation). The major findings of the study showed a significant relationship between Psychoticism and involvement in risky sexual Behavior $(\mathrm{r}=0.025)$. In conclusion the relationship is weak and positive hence psychotic personality is likely to participate in risky sex.
\end{abstract}

Keywords: Psychoticism, Risky Sexual Behavior and Strategic Counseling

\section{Introduction}

Momtaz and Mohammed [1] on the research topic: Sexual Risk among substance users and its relation to personality profile. 100 participants were used in the study. The quasi experimental design was used. The result showed that there was statistically significant difference in extroversion and neuroticism between cases of control. There were statistically significant difference between the cases and controls in terms of sexual sub scale of RAB. There was a significant correlation between Psychoticism and criminality sub scales in Eysenck personality questionnaire and the RAB in the case group. Whereas the study reviewed above entailed sexual risk among substance users and its relationship to personality. It did not single out risky sexual Behavior on its own hence the present study bridged the gap by looking into the relationship between personality and involvement in risky sexual Behavior.

Durvasula and Reagan [2] on the research title: Personality and sexual risk in HIV positive gay man. The present study examines the association between wide variety of personality variables and sexual risk factor because gay population has high HIV prevalence in the United States. A sample of 107 HIV positive gay was used in the study. Personality was assessed multi-dimensionally using MCMI - III, Personality Assessment Screener (PAS) NEO - PI - R, Sensation Seeking Sides (SSS) and a structured clinical interview to asses' personality disorders. The results revealed that a greater proportion of men with cluster B personality disorder (PD) diagnosis (borderline, narcissistic, antisocial or histrionic) reported having two or more sexual partners compared to those without a cluster BPD. Psychotic features, and hostile control scales were observed in men who reported consistent condom use(less risk). While the above reviewed study looks into risky sex and personality among gay men, it did not consider gay females and students. The present study bridged the gap by considering the students in the assessment of risky sexual Behavior. 
Annette, Elizabeth and Ostergen [3] on the study: Youth, Sexual risk - taking Behavior and mental health: A study of University students in Uganda. A sample of 980 students was used. Self administered questionnaire assessing socio demographic and religious background factors, mental health, alcohol use and sexual Behavior was used. The result showed that Psychoticism was also significantly associated with high numbers of sexual partners. Female students were found to be at more risk of engaging in risky sexual Behavior than their male counterparts. Whereas the above reviewed study focused on risky sex and mental health, the present study only focused on personality and how it is related to risky sex.

Brown, Lubman and pexton [4] on the topic: Sexual risk Behavior in young people with first episode psychosis. Sixty seven sexually active young people with first episode psychosis and 48 healthy control participants (aged 18 - 29) closely matched on assessing a comprehensive range of sexual risk Behavior. The result was that few differences in the rates of sexual risk Behavior were reported by the first episode sample and their peers. Compared with control participants, young people with the first episode psychosis reported significantly more inconsistent in condom use. Whereas the above reviewed literature focused on risky sexual Behavior among people with first episode of psychosis, it did not relate it with personality; hence the present study focused on normal people without psychosis and personality dimension was considered.

Unruh [5] on the dark triads and risky Behavior conducted a research with a sample of 115 under graduate college students using a survey design. Hierarchical regression analysis showed that there was a significant interaction between Psychoticism and life history on mating risk, which included engaging in unprotected sex and multiple sexual partnerships. The above reviewed study focuses on the dark triads: narcissism, Machiavellianism and psychopathy, neglecting the other personality dimensions. The present study bridged the gap by considering other personality dimensions.

Sonja and Stewart [6] on the research: risk taking Behavior and criminal offending; an investigation of sensation seeking and the Eysenck personality questionnaire. The research used 92 male offenders in two Southeast Queensland prisons. Eysenck's Psychoticism trait was demonstrated to be a clear marker of the more broad impulsive, unsocialized sensation seeking factor rather than representing a super-trait in its own right. While the above reviewed study focuses on risk taking Behavior and criminal offending among prisoners, leaving the youths and schools, the present bridged the gap by involving the youths and schools in the study of relationship between personality and involvement in risky sexual Behavior

Verhulst [7] on the research topic: the nature of the relationship between personality traits and political attitudes, conducted a survey research on a sample of 20,559 participants. The results indicated that Psychoticism was strongly related to conservative positions on punishment, religion and sex attitudes. Psychoticism and social attitudes were due to a common genetic influence. Whereas the above reviewed study focuses on personality traits and political attitudes, the aspect of risky sexual Behavior is left out. The present study bridged the gap by considering the aspects of risky sexual Behavior as part of sex attitudes.

Watson and Pulford [8] conducted a research on personality differences in high risk sport amateurs and instructors. The study involved 38 men and 28 women across three groups of participants. The results indicated that amateurs scored significantly higher on Psychoticism and self efficacy than the instructors and non-participants. Whereas the above reviewed study focuses on personality differences in high risk sports, the aspect of risky sexual Behavior is left out. The present study bridged the gap by investigating the relationship between Psychoticism and involvement in risky sexual Behavior.

Michael, Tandrea and Nadine [9] conducted a research on impact of Psychoticism on perceived hassles, depression, hostility and hopelessness in non-psychiatric Africans $(n=134)$. The results indicated that Psychoticism has substantial effect on several important characteristics: perceived daily hassles, depression and hostility. Depression mediated the association between Psychoticism and hopelessness. Psychoticism appears to cause meaningful dysfunction even among non-psychiatric individuals. Whereas the reviewed study focuses on impact of Psychoticism, its relationship with risky sexual Behavior is not explored. The present study bridged the gap by considering relationship between Psychoticism and involvement in risky sexual Behavior.

Ndetei [10] conducted a cross sectional study of cooccurring suicidal risk and Psychoticism in Nairobi $(n=691)$. The results indicated that significant positive correlation $(\mathrm{p}<0.05)$ between Psychoticism and suicidal symptoms. Whereas the above reviewed literature involves a cross sectional study in Nairobi, the student population was left out. The present study bridged the gap by investigating the relationship between Psychoticism and risky sexual Behavior.

Kaijaleena [11] on research dissertation university students attitudes towards HIV/AIDS in Finland and Kenya using comparative study among 525 first year students(Finnish 411 and Kenyan 114) reported that sexual risk was significantly related to psychotic signs. Whereas the reviewed study focuses on students' attitude towards HIV/AIDS, the idea of personality and risky sexual Behavior is left out. The present study bridged the gap by considering personality and Psychoticism.

Otieno [12] reported on the risky HIV sexual Behavior and depression among university of Nairobi students and found out that prevalence rates of HIV infection among the youth are disproportionately high compared to that of other age groups in Kenya. The percentage of those who had even been diagnosed with sexually transmitted infections was $9.71 \%$ and for HIV was $3.04 \%$. Nearly $30 \%$ reported having had multiple partners in the previous 12 months, $27.4 \%$ of the 
students did not use condoms with sexual partners and $21 \%$ had engaged in sex after drinking within the previous 3 months.

UNAIDS report [13] on prevention of HIV among young people found out that condom use among young people with multiple partners stood at $67.3 \%$ for males and $37.1 \%$ among females. It was also noted that the young people were aged 15 to 24 years. The cumulative HIV data (children 14 years and above) from 2012 to 2014 were as follows in Nyakach: 50332 children were under cotrimoxazol therapy for HIV, 6 under WHO stage 4, 260 under WHO stage 1, 608 under prophlysis therapy, 215 under WHO stage 2, 19 enrolled ART, 68 enrolled ART PMTCT, 34 on PEP and 581 not started on ART (KHIS, 2014) [14].

Following the KHIS data [14] for people living with HIV/AIDS in Nyakach Sub County, it is evident that persistence in risky sexual Behavior is a major problem among the residents of Nyakach especially among young people. The causes of high prevalence of risky sexual Behavior in Nyakach may be attributed to socioeconomic, cultural, developmental and Behavioral aspects of life. As it is observed from the above literature and data from international level to local level, risk sexual Behavior is a significant issue affecting young people in schools in various ways. The present study therefore sought to establish the relationship between Psychotic personality subtypes and involvement in risky sexual behavior among the secondary school students in Nyakach Sub County, Kenya. The following hypotheses were tested: $\mathrm{H}_{\mathrm{A}}$ : There is statistically significant relationship between Psychoticism personality subtype and involvement in risky sexual Behavior. $\mathrm{H}_{\mathrm{O}}$ : There is no statistically significant relationship between Psychoticism personality subtype and involvement in risky sexual Behavior.

\section{Methodology}

A correlational research design [43] was used to study extraversion and involvement in risky sexual Behavior considering the target population of 15,678 students in 54 secondary schools in Nyakach. A multistage random sampling was done at divisional level, school and class room level. A sample size of 46 schools $(88 \%)$ and 390 students $(22 \%)$ was obtained. The following are sampling matrices

Table 1. Sampling matrix for respondents.

\begin{tabular}{|c|c|c|c|c|}
\hline Sample units & $\begin{array}{l}\text { Sampling } \\
\text { method }\end{array}$ & $\begin{array}{l}\text { Target } \\
\text { population }\end{array}$ & $\begin{array}{l}\text { Sample } \\
\text { size } \\
\end{array}$ & Percentage \\
\hline Schools & $\begin{array}{l}\text { Simple } \\
\text { random }\end{array}$ & 52 & 46 & $88 \%$ \\
\hline Students & $\begin{array}{l}\text { Simple } \\
\text { random }\end{array}$ & 15,678 & 390 & $22 \%$ \\
\hline Division & $\begin{array}{l}\text { Simple } \\
\text { random }\end{array}$ & 3 & 3 & $100 \%$ \\
\hline
\end{tabular}

The Eysenck's personality questionnaire (EPQ) [21] and risky sexual Behavior questionnaire [22] were administered to the sampled participants. Once the research permits from university or NACOSTI had been granted, letters of transmittal were prepared and personally delivered to prospective and respective participant to seek their willingness and consent to participate in the study. Two days were used to get and fix appointments dates. On the dates of data collection, the Researcher supervised the administering of the instruments personally. Accuracy in data recording was emphasized by confirming key issues with respondents before closing the session. The exercise of data collection took a week; each respondent was given at least 20 minutes to fill questionnaires. The quantitative data collected from the study was analyzed in different ways using the version 19 of SPSS. During the study, a number of ethical considerations were maintained. The potential research participants were provided with information which enabled them to make an informed decision as to whether they want to participate in the research study or not. The informed consent was obtained from respective school heads and students, who were the informant. The confidentiality was upheld at all cost by ensuring there were no details in the questionnaire which could reveal the identity of the participants.

\section{Results and Discussion}

\subsection{Questionnaires Return Rate}

There was $100 \%$ response rate for schools since the questionnaires were administered to students in all the sampled 46 schools in Nyakach Sub-County. This was achieved because the researcher made sure he visited all the sampled schools during data collection. However, there was $99.7 \%$ return rate of questionnaires for students (Table 2) in which all the questions in the questionnaires were answered. The high questionnaire return rate was achieved because the researcher made call backs and administered the instruments to each respondent in person to ensure that each and every respondent took part in the study. However, one of the student respondents did not fully complete the questionnaire having filled in most of the answers but failed to answer some parts. This lead to the less than $100 \%$ return rate. Table 2 shows the comprehensive questionnaire return rate for different categories of respondents and sample target.

Table 2. Questionnaire Return Rate.

\begin{tabular}{llll}
\hline $\begin{array}{l}\text { Respondent } \\
\text { category }\end{array}$ & $\begin{array}{l}\text { Number targeted } \\
\text { for response }\end{array}$ & $\begin{array}{l}\text { Number who } \\
\text { responded }\end{array}$ & $\begin{array}{l}\text { Percentage } \\
\text { response rate }\end{array}$ \\
\hline Boys Schools & 2 & 2 & $100 \%$ \\
Girls Schools & 3 & 3 & $100 \%$ \\
Mixed Schools & 41 & 41 & $100 \%$ \\
Students & 390 & 389 & $99.7 \%$ \\
\hline
\end{tabular}

Source: Researcher's data

\subsection{Respondents Demographic Characteristics}

Student respondents' sex

The respondent's sex was very important in this study and the findings are presented in table 3 . 
Table 3. Student Respondents sex.

\begin{tabular}{lllll}
\hline & Male & & Female & \\
\hline Respondent Category & Frequency & Percentage & Frequency & Percentage \\
\hline Boys Schools & 22 & $100 \%$ & - & - \\
Girls' schools & - & - & 30 & $100 \%$ \\
Mixed Schools & 169 & $50.1 \%$ & 168 & $49.9 \%$ \\
Overall & 191 & $49.1 \%$ & 198 & $50.9 \%$ \\
\hline
\end{tabular}

Source: Researcher's data

Considering the response by sex, majority of the student respondents were girls $(58.3 \%)$ with boys making only $41.7 \%$. this could be attributed to the fact that more girls schools (3) than Boys Schools (2) were sampled. However, in the mixed schools, there were $53.2 \%$ boys respondents to $46.8 \%$ girls' respondents. A previous study by Annette, Elizabeth and Ostergren [15] found that female students are more at risk or susceptible to risky sexual Behavior. Therefore, the sex distribution in this study was evenly distributed about the average with males and females balancing out about the $50 \%$ average.

\subsection{Psychoticism and Involvement in Risky Sexual Behavior}

The fourth objective of the study was to investigate the relationship between the Psychoticism and involvement in risky sexual Behavior. Psychoticism is characterized by overzealous aggressiveness and interpersonal hostility (Peterson, Geher and Kaufman, 2011) [23]. This study interviewed 389 students from which students were gauged on their score on the psychotic scale. From the analysis of the responses, students showing significant level of psychoticism were categorized as psychotic and their opinion on risky sexual Behavior were analyzed and deemed to represent the perspective of psychoticism.

\subsection{Determining Psychoticism Personality Sub-type}

All the 389 student respondents who completed the survey by answering the questionnaires gave their opinion on how they considered themselves based on questions on the psychoticism scale. Their responses were given on a scale of strongly disagree to strongly agree. The response of the 389 student respondents are shown in the table 4.

Table 4. Students Response on the Psychoticism Scale.

\begin{tabular}{|c|c|c|c|c|c|c|c|}
\hline NO. & Psychoticism Scale & SD & D & $\mathbf{U}$ & $\mathbf{A}$ & $\mathbf{S A}$ & Total \\
\hline 1 & I always have fun running into walls & $\begin{array}{l}194 \\
(49.9 \%)\end{array}$ & $\begin{array}{l}165 \\
(42.4 \%)\end{array}$ & $\begin{array}{l}22 \\
(5.7 \%)\end{array}$ & $\begin{array}{l}7 \\
(1.8 \%)\end{array}$ & $\begin{array}{l}1 \\
(0.3 \%)\end{array}$ & $\begin{array}{l}389 \\
(100 \%)\end{array}$ \\
\hline 2 & I always feel vegetables are oppressed & $\begin{array}{l}247 \\
(63.5 \%)\end{array}$ & $\begin{array}{l}134 \\
(34.4 \%)\end{array}$ & $\begin{array}{l}0 \\
(0.0 \%)\end{array}$ & $\begin{array}{l}6 \\
(1.5 \%)\end{array}$ & $\begin{array}{l}2 \\
(0.5 \%)\end{array}$ & $\begin{array}{l}389 \\
(100 \%)\end{array}$ \\
\hline 3 & I always eat soap & $\begin{array}{l}184 \\
(47.3 \%)\end{array}$ & $\begin{array}{l}196 \\
(50.4 \%)\end{array}$ & $\begin{array}{l}3 \\
(0.8 \%)\end{array}$ & $\begin{array}{l}5 \\
(1.3 \%)\end{array}$ & $\begin{array}{l}1 \\
(0.3 \%)\end{array}$ & $\begin{array}{l}389 \\
(100 \%)\end{array}$ \\
\hline 4 & I always beat people with sticks & $\begin{array}{l}298 \\
(76.6 \%)\end{array}$ & $\begin{array}{l}79 \\
(20.3 \%)\end{array}$ & $\begin{array}{l}6 \\
(1.5 \%)\end{array}$ & $\begin{array}{l}4 \\
(1.0 \%)\end{array}$ & $\begin{array}{l}2 \\
(0.5 \%)\end{array}$ & $\begin{array}{l}389 \\
(100 \%)\end{array}$ \\
\hline 5 & Giant sheep-cows always invade me & $\begin{array}{l}207 \\
(53.2 \%)\end{array}$ & $\begin{array}{l}171 \\
(44.0 \%)\end{array}$ & $\begin{array}{l}3 \\
(0.8 \%)\end{array}$ & $\begin{array}{l}6 \\
(1.5 \%)\end{array}$ & $\begin{array}{l}2 \\
(0.5 \%)\end{array}$ & $\begin{array}{l}389 \\
(100 \%)\end{array}$ \\
\hline 6 & I can always amuse myself with a pen for a few hours & $\begin{array}{l}76 \\
(19.5 \%)\end{array}$ & $\begin{array}{l}301 \\
(77.4 \%)\end{array}$ & $\begin{array}{l}4 \\
(1.0 \%)\end{array}$ & $\begin{array}{l}6 \\
(1.5 \%)\end{array}$ & $\begin{array}{l}2 \\
(0.5 \%)\end{array}$ & $\begin{array}{l}389 \\
(100 \%)\end{array}$ \\
\hline 7 & I am always amused by the slightest things (such as. lights) & $\begin{array}{l}127 \\
(32.6 \%)\end{array}$ & $\begin{array}{l}209 \\
(53.7 \%)\end{array}$ & $\begin{array}{l}45 \\
(11.6 \%)\end{array}$ & $\begin{array}{l}6 \\
(1.5 \%)\end{array}$ & $\begin{array}{l}2 \\
(0.5 \%)\end{array}$ & $\begin{array}{l}389 \\
(100 \%)\end{array}$ \\
\hline 8 & I always dance around after scaring someone & $\begin{array}{l}223 \\
(57.3 \%)\end{array}$ & $\begin{array}{l}139 \\
(35.7 \%)\end{array}$ & $\begin{array}{l}17 \\
(4.4 \%)\end{array}$ & $\begin{array}{l}5 \\
(1.3 \%)\end{array}$ & $\begin{array}{l}5 \\
(1.3 \%)\end{array}$ & $\begin{array}{l}389 \\
(100 \%)\end{array}$ \\
\hline 9 & I always run around with a scarf wrapped around my head & $\begin{array}{l}279 \\
(71.7 \%)\end{array}$ & $\begin{array}{l}102 \\
(26.2 \%)\end{array}$ & $\begin{array}{l}0 \\
(0.0 \%)\end{array}$ & $\begin{array}{l}5 \\
(1.3 \%)\end{array}$ & $\begin{array}{l}3 \\
(0.8 \%)\end{array}$ & $\begin{array}{l}389 \\
(100 \%)\end{array}$ \\
\hline & Average & $\begin{array}{l}204 \\
(52.4 \%)\end{array}$ & $\begin{array}{l}166 \\
(42.7 \%)\end{array}$ & $\begin{array}{l}11 \\
(2.9 \%)\end{array}$ & $\begin{array}{l}6 \\
(1.4 \%)\end{array}$ & $\begin{array}{l}2 \\
(0.6 \%)\end{array}$ & $\begin{array}{l}389 \\
(100 \%)\end{array}$ \\
\hline
\end{tabular}

Source: Researcher's data (2015) $n=389$

Out of the 389 student respondents who gave their responses on the Psychoticism scale, only 8 (2.1\%) scored highly. This number agreed to: having fun running into walls; feeling that vegetables are oppressed; that giant sheep-cows always invade them and that they dance around with a scarf wrapped around their heads. However, the number of student respondents who agreed to the statement that they dance around after scaring someone was slightly higher at 10
(2.6\%). These figures included those who just agreed and those who strongly agreed. These findings are consistent with those of Sonja and Sterwart [6] who reported Psychoticism to be clear marker of broad impulsive, unsocial zed sensation seeking rather than representing a super trait on its own. Students who scored highly on the Psychoticism scale were considered to represent Psychoticism. However, these student respondents still showed high levels of the other personality 
subtypes. The argument by the researcher was that if they could show such a significantly high score on the Psychoticism scale (based on the questions of the scale) then they were viable as psychotics.

\subsection{Psychoticism and Risky Sexual Behavior}

The fourth objective of the study sought to determine the relationship between Psychoticism personality subtype and involvement in risky sexual Behavior. The researcher analyzed the performance of students who scored highly on the Psychoticism scale $(n=8)$ on the risky sexual Behavior scale. The score on various items on the risky sexual Behavior scale was considered to make conclusion on their opinion and vulnerability towards engaging in risky sexual Behavior. Aspects such as carelessness towards sexual activities, attitude and use of condom, drug and alcohol use as well as the tendency to be influenced or swayed into compromising and engaging into risky sexual Behavior were analyzed and are presented in the table 5 .

Table 5. Psychoticism Performance on the Risky Sexual Behavior Scale.

\begin{tabular}{|c|c|c|c|c|c|c|}
\hline Psychoticism Sexual Risks Scale & SD & D & $\mathbf{U}$ & $\mathbf{A}$ & SA & Total \\
\hline If my partner wanted me to have unprotected sex, I would probably give in & $\begin{array}{l}0 \\
(0.0 \%)\end{array}$ & $\begin{array}{l}4 \\
(50.0 \%)\end{array}$ & $\begin{array}{l}1 \\
(12.5 \%)\end{array}$ & $\begin{array}{l}2 \\
(25.0 \%)\end{array}$ & $\begin{array}{l}1 \\
(12.5 \%)\end{array}$ & $\begin{array}{l}8 \\
(100 \%)\end{array}$ \\
\hline If I were going to have sex, I would take precautions to reduce my risk of HIV/AIDS & $\begin{array}{l}0 \\
(0.0 \%)\end{array}$ & $\begin{array}{l}1 \\
(12.5 \%)\end{array}$ & $\begin{array}{l}1 \\
(12.5 \%)\end{array}$ & $\begin{array}{l}4 \\
(50.0 \%)\end{array}$ & $\begin{array}{l}2 \\
(25.0 \%)\end{array}$ & $\begin{array}{l}8 \\
(100 \%)\end{array}$ \\
\hline Condoms ruin the natural sex act & $\begin{array}{l}2 \\
(25.0 \%)\end{array}$ & $\begin{array}{l}1 \\
(12.5 \%)\end{array}$ & $\begin{array}{l}3 \\
(37.5 \%)\end{array}$ & $\begin{array}{l}1 \\
(12.5 \%)\end{array}$ & $\begin{array}{l}1 \\
(12.5 \%)\end{array}$ & $\begin{array}{l}8 \\
(100 \%)\end{array}$ \\
\hline I would try to use a condom when I had sex & $\begin{array}{l}1 \\
(12.5 \%)\end{array}$ & $\begin{array}{l}7 \\
(87.5 \%)\end{array}$ & $\begin{array}{l}0 \\
(0.0 \%)\end{array}$ & $\begin{array}{l}0 \\
(0.0 \%)\end{array}$ & $\begin{array}{l}0 \\
(0.0 \%)\end{array}$ & $\begin{array}{l}8 \\
(100 \%)\end{array}$ \\
\hline Generally, I am in favour of using condoms & $\begin{array}{l}2 \\
(25.0 \%)\end{array}$ & $\begin{array}{l}0 \\
(0.0 \%)\end{array}$ & $\begin{array}{l}1 \\
(12.5 \%)\end{array}$ & $\begin{array}{l}1 \\
(12.5 \%)\end{array}$ & $\begin{array}{l}4 \\
(50.0 \%)\end{array}$ & $\begin{array}{l}8 \\
(100 \%)\end{array}$ \\
\hline I would avoid using condoms if at all possible & $\begin{array}{l}1 \\
(12.5 \%)\end{array}$ & $\begin{array}{l}0 \\
(0.0 \%)\end{array}$ & $\begin{array}{l}2 \\
(25.0 \%)\end{array}$ & $\begin{array}{l}1 \\
(12.5 \%)\end{array}$ & $\begin{array}{l}4 \\
(50.0 \%)\end{array}$ & $\begin{array}{l}8 \\
(100 \%)\end{array}$ \\
\hline If I had a date, I would probably not drink alcohol or use drugs & $\begin{array}{l}1 \\
(12.5 \%)\end{array}$ & $\begin{array}{l}2 \\
(25.0 \%)\end{array}$ & $\begin{array}{l}2 \\
(25.0 \%)\end{array}$ & $\begin{array}{l}1 \\
(12.5 \%)\end{array}$ & $\begin{array}{l}2 \\
(25.0 \%)\end{array}$ & $\begin{array}{l}8 \\
(100 \%)\end{array}$ \\
\hline The idea of using a condom doesn't appeal to me & $\begin{array}{l}1 \\
(12.5 \%)\end{array}$ & $\begin{array}{l}1 \\
(12.5 \%)\end{array}$ & $\begin{array}{l}2 \\
(25.0 \%)\end{array}$ & $\begin{array}{l}1 \\
(12.5 \%)\end{array}$ & $\begin{array}{l}3 \\
(37.5 \%)\end{array}$ & $\begin{array}{l}8 \\
(100 \%)\end{array}$ \\
\hline With condoms, you can't really give yourself over to your partner & $\begin{array}{l}1 \\
(12.5 \%)\end{array}$ & $\begin{array}{l}2 \\
(25.0 \%)\end{array}$ & $\begin{array}{l}1 \\
(12.5 \%)\end{array}$ & $\begin{array}{l}1 \\
(12.5 \%)\end{array}$ & $\begin{array}{l}3 \\
(37.5 \%)\end{array}$ & $\begin{array}{l}8 \\
(100 \%)\end{array}$ \\
\hline My sexual experiences do not put me at risk of HIV/AIDS & $\begin{array}{l}2 \\
(25.0 \%)\end{array}$ & $\begin{array}{l}0 \\
(0.0 \%)\end{array}$ & $\begin{array}{l}1 \\
(12.5 \%)\end{array}$ & $\begin{array}{l}2 \\
(25.0 \%)\end{array}$ & $\begin{array}{l}3 \\
(37.5 \%)\end{array}$ & $\begin{array}{l}8 \\
(100 \%)\end{array}$ \\
\hline When I socialize, I usually drink alcohol or use drugs & $\begin{array}{l}2 \\
(25.0 \%)\end{array}$ & $\begin{array}{l}0 \\
(0.0 \%)\end{array}$ & $\begin{array}{l}1 \\
(12.5 \%)\end{array}$ & $\begin{array}{l}5 \\
(62.5 \%)\end{array}$ & $\begin{array}{l}0 \\
(0.0 \%)\end{array}$ & $\begin{array}{l}8 \\
(100 \%)\end{array}$ \\
\hline If I were going to have sex in the next year, I would use condoms & $\begin{array}{l}2 \\
(25.0 \%)\end{array}$ & $\begin{array}{l}1 \\
(12.5 \%)\end{array}$ & $\begin{array}{l}4 \\
(50.0 \%)\end{array}$ & $\begin{array}{l}1 \\
(12.5 \%)\end{array}$ & $\begin{array}{l}0 \\
(0.0 \%)\end{array}$ & $\begin{array}{l}8 \\
(100 \%)\end{array}$ \\
\hline $\begin{array}{l}\text { If a sexual partner didn't want to use condoms, we would have sex without using } \\
\text { condoms }\end{array}$ & 2 & $\begin{array}{l}0 \\
(0.0 \%)\end{array}$ & $\begin{array}{l}1 \\
(12.5 \%)\end{array}$ & $\begin{array}{l}2 \\
(25.0 \%)\end{array}$ & $\begin{array}{l}3 \\
(37.5 \%)\end{array}$ & $\begin{array}{l}8 \\
(100 \%)\end{array}$ \\
\hline People can get the same pleasure from safer sex as from unprotected sex & $\begin{array}{l}3 \\
(37.5 \%)\end{array}$ & $\begin{array}{l}0 \\
(0.0 \%)\end{array}$ & $(25.0 \%)$ & $\begin{array}{l}2 \\
(25.0 \%)\end{array}$ & $\begin{array}{l}1 \\
(12.5 \%)\end{array}$ & $\begin{array}{l}8 \\
(100 \%) \\
\end{array}$ \\
\hline
\end{tabular}

Researchers data, $2015(n=8)$

The study found that student respondents showing strong Psychoticism are not steady on their decisions. For example 3 $(37.5 \%)$ of the respondents agreed that if their partner wanted them to have unprotected sex, they would probably give in. a majority of the respondents in this category which were 5 $(62.5 \%)$ of the respondents admit that they would avoid using condoms if at all possible. This is consistent with the findings of Kelleher [24] who found that one of the major Psychotic symptoms in adolescence is that they take highly risky choices which might endanger their lives. A similar number agreed that if a sexual partner didn't want to use condoms, they would have sex without using condoms. These findings are consistent with that of Unruh [5] who reported that Psychoticism is associated with unprotected sex and multiple partnerships. The most interesting statistic is that all $(100 \%)$ of the respondents who scored highly on Psychoticism scale disagree with the statement that they would try to use a condom when they had sex. This implies that they will not make any effort to protect themselves. According to Kopele and Shumba [25] in their research on 'Sexual Behaviors and Attitude towards safer sex of Psychology students at a South Africa University Campus', students attitude towards safe sex is measured by their attitude towards the use of condoms which vary from one personality subtype to the next. These findings are concurrent with those of Verhulst [7] who reported that Psychoticism is strongly related with sex attitudes and Durvasula and Reagan [2] who reported that psychotics' features were associated with inconsistent condom use. They further added that Psychoticism shows extremely negative attitude towards condom use. On the risky sexual Behavior, the study found that respondents scoring highly on the Psychoticism are more likely to engage in activities that make them vulnerable. For example, 5 $(62.5 \%)$ of the respondents admitted that when they socialize, they usually drink alcohol or use drugs. Lubman [4] found that 
Psychoticism increase the chances of involving in drug abuse which enhance risky sexual Behavior. Psychoticism is significantly associated with multiple partnerships (Annette et al), [3].

\subsection{Correlation Between Psychoticism and Involvement in Risky Sexual Behavior}

A two tailed Bivariate Pearson correlation coefficient to establish whether a relationship exists between Psychoticism and their tendency to involve in risky sexual Behavior. The results are shown in the table 6.

Table 6. Correlation -Psychoticism and Involvement in Risky sexual Behavior.

\begin{tabular}{lll}
\hline Personality subtype & Statistic & Risky Sexual Behavior \\
\hline \multirow{3}{*}{ Psychoticism } & Pearson Correlation & $.025^{*}$ \\
& Sig. (2-tailed) & .036 \\
& N & 8 \\
\hline
\end{tabular}

*Correlation is significant at the 0.05 level (2 tailed)

Source: Researcher's Analysis

The results indicate a strong positive correlation between the Psychoticism and involvement in risky sexual Behavior of $\mathrm{r}=$ 0.025 which is statistically significant at $\mathrm{P}<0.05$ since our Two-tailed significance is 0.036 . The results imply that increases in Psychoticism will results into an increase in the tendency to involve in risky sexual Behavior. Similar findings were reported by Kaijaleena [11] that sexual risk Behavior is significantly related to Psychoticism. Also Watson and Pulford [8] reported that Psychoticism involve themselves more in high risk activities. Since significant level 0.036 is less than common alpha 0.05 we reject $\mathrm{H}_{\mathrm{O}}$ : There is no statistically significant relationship between Psychoticism personality subtype and involvement in risky sexual Behavior, and adopt $\mathrm{H}_{\mathrm{A}}$ : There is a statistically significant relationship between Psychoticism personality and involvement in risky sexual Behavior. These findings are in line with Ndetei [10] who reported a significant relationship between Psychoticism and risk taking in suicidality.

\section{Conclusion}

In conclusion the study found that student respondents showing strong Psychoticism are not steady on their decisions. The study also found that a majority of individuals showing Psychoticism will not make any effort at protecting themselves against unsafe sex. On the risky sexual Behavior, the study found that respondents scoring highly on the Psychoticism are more likely to engage in activities that make them vulnerable to risky sex. There is a statistically significant correlation between Psychoticism and involvement in risky sexual Behavior at $\mathrm{P}<0.05$. The study recommended that categorizing and profiling the students into their most dominant personality subtypes by teacher counselors will be one way that can be used to offer strategic counseling so as to handle various students depending on their personality subtypes, this study proposes" personality centered counseling approach."

\section{References}

[1] Momtaz, A. and Mohammed, E. A. (2012). Sexual Risk among Substance Users and its Relation to Personality Profile. A Psychology Journal. 33 (3) 135-141.

[2] Durvasula, R. and Reagan, P. (2015). Personality and sexual among Gaymen. In Chhabra (E.d), Proceeding of international conference on Cognitive and Behavioral Psychology Pp 124-131) Singapore. Global Science for Technology Forum.

[3] Annette, A., Petterson, K. O. and Ostergren, P. (2011). Experience of Sexual Coercion and Risky Sexual Behavior among Ugandan University Students. A Journal on Public Health. 20 (11) 527.

[4] Lubman, A. et al (2010). Sexual risk Behavior in young people with first episode psychosis. Journal of Behavior, 20(9): $168-212$.

[5] Unruh, T., Hesher, T. and Hill, T. (2015). The triad and risky Behavior. DSEL Research Group. 26(20) 778-844.

[6] Sonja, K. and Stewart, A. L. (2014). Risk taking Behavior and criminal offending: an Investigation of sensation seeking and the Eysenck's personality questionnaire. Personality journal. 4(6): 14-25.

[7] Verhulst, B. (2010). The nature of relationship between personality traits and political attitudes. Personality and individual difference. 49(10) 306-316.

[8] Watson, A. E. and Pulford, B. D. (2010). Personality differences in high risk sport amateurs and instructors. Perceptual and motor skills. 99(1) 83-94.

[9] Michael, T. C., Tandarea, C. and Nadine, J. K. (2009). The impact of Psychoticism on Perceived hassles, depression, hostility and hopelessness in non-psychiatric Africans. Psychiatry Res. 159(1-2): 215-225.

[10] Ndetei, D. M. et al (2009) A cross-sectional study of cooccurring suicidal and psychotic Symptoms in inpatients at Mathari psychiatric hospital, Nairobi, Kenya. Prim care companion journal of clinical psychiatry. 11(3): 110-114.

[11] Kaijaleena, S. (2008). University students attitudes towards HIVIAID Sin Finland and Kenya. Academic dissertation. University of Oulu, Department of Medicine.

[12] Otieno, C. J. and Okoth, R. (2015). Risky HIV Sexual Behavior and depression among University of Nairobi Students. Annals of Generally Psychiatric Journal. 15 (14) 16.

[13] UNAIDS Report (2008). Report on global AIDS epidemic. www.unaids.org.com

[14] District Health Information Software (2014). www.his.org

[15] Annette, A, Elizabeth, C. G. and Ostergren, P. (2012). Youths Sexual Risk Taking Behavior and Mental Health. $A$ psychological Journal. 19 (2) 208-216.

[16] Annette, A., Elizabeth, C. G. and Ostergren, P. O. (2012). Youth sexual risk taking Behavior and mental health: a study of University Students in Uganda. International journal of behavioral medicine. 19(12)208-216. 
[17] Adrienne, T. \&Bichsel, J. (2014), Association between self rated health and personality. US National Library of Medicine, National institutes of Health Ethn Dis Autumn: 24(4): 418-22.

[18] Anteneh, Z. A. (2013). Prevalence and Correlates of multiple sexual Partnerships among Private college students in Bahirdar City, North West Ethiopia. Science journal of Public Health; 1(1): 9-17.

[19] Asante, M. etal (2014). Substance use and risky sexual Behavior among street connected Children. Journal of Psychology, 14(6): 123-144.

[20] Eysenck, H. J. and Sybil, B. G. (1975). Eysenck's personality inventory. Educational and Industrial testing services. San Diego California 92107.

[21] Alvergne, A., Markus, J. and Charlotte, F. (2010). Personality and testosterone in men from a high fertility population. Personality and individual difference Journal. 49(10) 840-844

[22] Peterson, A. Geher, G. and Kaufman, S. B. (2011). Predicting preferences for sex act: which Trait matters and why? Evolution Psychology journal, 9, 371-389.

[23] Kelleher, I. etal (2012). Psychotic symptoms in adolescence index risk for suicidal Behavior. Arch Gen Psychiatry. 69 (12): $1277-1283$.

[24] Kopele, B. and Shumba, A. (2011). Sexual Behaviors and Altitude towards safer sex of Psychology students at a South Africa University Campus. Kamla Raj enterprises 13(4): 257.

[25] Berhan, Y. and Berhan, A. (2015). A Meta analysis of sexual Behavior among Youth in Developing Countries. Journal on AIDS Research and Treatment. 20(15) 1-9.

[26] Bareld, D. P. H. and Dijksta, P. (2011). Positive illusions about a partner's personality and Relationship quality. Journal of research in personality, 45(1)37-43.

[27] Booysen, F. R. \& Summerton, J. (2011). Poverty, Risky Sexual Behavior Vulnerability to HIV infection: Evidence from South Africa. Journal of Health, population and Nutrition: 20(4): 285-288.

[28] Brodish, J. et al (2011). Evidence of high risk sexual Behavior among infection drug users in Kenya. PLACE study. Public Health Journal, 8(9) 112-123.

[29] [30 Deresse, D. and Debebe, S. (2014). Magnitude of risky sexual Behavior among High School Students in Ethiopia. Journal of public Health and epidemiology. 6(7) 21-215.

[30] Ertac, S. and Gurdal, M. Y. (2012). Personality, group decision making and leadership. Paper provided by KOC university-TUSIAD. Economic research forum. Paper with number 1227.

[31] Gong, E. (2015). HIV Testing and Risky Sexual Behavior: The Nothing to lose effect. Royal economic Society: London.
[32] Gemedu, E. S. and Worku, B. (2014). Risky Sexual Behavior for STI / HIV infection among Alakan University Student in Ethiopia. Science Post Print. 11 (85) 8-9.

[33] Henderson, N. et al (2012). An overview of prevention of multiple risk Behavior in Adolescent and childhood. Adolescent and childhood Behavior, 12(55): 166-232.

[34] Jeneice, L. S. (2013). Perceived susceptibility to negative Consequences of Risky Sexual Behavior among College Students. ABC Books.

[35] Kenyaforumnet (2013). People living with HIV. Kenyaforumnet.com.

[36] Kenya AIDS Survey Indicator report (2012). National AIDS Control Council. www.nacc.or.ke.

[37] Krista, K. J., Jeffrey, H. H., Henry, L. M. and Paul, T. C. (2002). Personality path way to safe Sex: Personality, condom use and HIV risk Behaviors. Journal of personality. 36(2): 117-133.

[38] Luke, N. (2010). Risky Sex in Urban Kenya: The Bitter of Sugar Daddy Affair. Pop line Journal: 8 (4) 3-4.

[39] Silas, J. (2013). Poverty and Risky Sexual Behavior Evidence from Tanzania, Courtesy of USAID. DHS Working Papers, USAID: No. 88.

[40] Soboka, B. and Gemedu, K. (2015). Assessment of Risky Sexual Behavior among Arba Minch University Students Arba Minch Town. Journal of child of child and adolescent Behavior. 3(1) 189-194.

[41] Serder, T. (2011). The Big Five Personality Traits and Risky Sport Participation. Ege University. Social Behavior and Personality Journal. 39 (8) 1105-1112.

[42] Shuper, P. A, Narges, J. and Rehm, J. (2013). Personality as a Predictor of unprotected Sexual Behavior among people living with HIV/AIDS. Springer Science Media. New York.

[43] Tegang, B. \& Emukule, M. (2010). Concurrent sexual and substance use risk Behavior Among Female workers in Kenya coast province. Psychological Journal, 8(32) 344-367.

[44] Terzian, A. \& Kristine M (2011). Preventing Multiple Risky Behaviors among Adolescents: Brief. Publication // 2011-24.

[45] Wilson, N. L, Wentao, X. \& Mattson, C. (2012). Is sex like Driving? Risk Compensation in Associated with Randomized Male Circumcision in Kisumu, Kenya No. 2011 - 09 Centres for Development Economics, Department of Economics, Will Sons College.www.kenyaforum.net/2013/07/29/countiesmosthitby-hivaids-in-kenya/.

[46] Zietsch, B. P. et al. (2010). Generic and Environmental influence on risky sexual Behavior and Its relationship with personality. University of Queensl and Behavior genetics, 40, $12-21$ (IF: 2.8). 2201-2796. 